\title{
Roles of Glutathione in Mediating Abscisic Acid Signaling and Its Regulation of Seed Dormancy and Drought Tolerance
}

\author{
Murali Krishna Koramutla, Manisha Negi (D) and Belay T. Ayele *(D) \\ Department of Plant Science, 222 Agriculture Building, University of Manitoba, Winnipeg, MB R3T 2N2, Canada; \\ murali.koramutla@umanitoba.ca (M.K.K.); Manisha.Negi@umanitoba.ca (M.N.) \\ * Correspondence: belay.ayele@umanitoba.ca; Tel.: +1-204-474-8227; Fax: +1-204-474-7528
}

Citation: Koramutla, M.K.; Negi, M.; Ayele, B.T. Roles of Glutathione in Mediating Abscisic Acid Signaling and Its Regulation of Seed Dormancy and Drought Tolerance. Genes 2021, 12, 1620. https://doi.org/10.3390/ genes12101620

Academic Editors: Sonia Gazzarrini and Eiji Nambara

Received: 2 September 2021

Accepted: 13 October 2021

Published: 14 October 2021

Publisher's Note: MDPI stays neutral with regard to jurisdictional claims in published maps and institutional affiliations.

Copyright: (c) 2021 by the authors. Licensee MDPI, Basel, Switzerland. This article is an open access article distributed under the terms and conditions of the Creative Commons Attribution (CC BY) license (https:// creativecommons.org/licenses/by/ $4.0 /)$.

\begin{abstract}
Plant growth and development and interactions with the environment are regulated by phytohormones and other signaling molecules. During their evolution, plants have developed strategies for efficient signal perception and for the activation of signal transduction cascades to maintain proper growth and development, in particular under adverse environmental conditions. Abscisic acid (ABA) is one of the phytohormones known to regulate plant developmental events and tolerance to environmental stresses. The role of ABA is mediated by both its accumulated level, which is regulated by its biosynthesis and catabolism, and signaling, all of which are influenced by complex regulatory mechanisms. Under stress conditions, plants employ enzymatic and nonenzymatic antioxidant strategies to scavenge excess reactive oxygen species (ROS) and mitigate the negative effects of oxidative stress. Glutathione (GSH) is one of the main antioxidant molecules playing a critical role in plant survival under stress conditions through the detoxification of excess ROS, maintaining cellular redox homeostasis and regulating protein functions. GSH has recently emerged as an important signaling molecule regulating ABA signal transduction and associated developmental events, and response to stressors. This review highlights the current knowledge on the interplay between ABA and GSH in regulating seed dormancy, germination, stomatal closure and tolerance to drought.
\end{abstract}

Keywords: abscisic acid; glutathione; dormancy; germination; stomatal closure; drought

\section{Introduction}

Plants are sessile in nature and are constantly exposed to a variety of environmental conditions that negatively affect their growth, development and productivity. However, they have evolved efficient signal perception and transduction mechanisms to combat these factors and sustain their growth and development. Previous studies have shown the involvement of phytohormones and other signal molecules in regulating plant developmental processes and their response to stress factors [1,2]. Abscisic acid (ABA) is one of the classical phytohormones considered to be a major player in this regard [3]. The response of plants to abiotic stressors usually involves activation of the ABA signaling cascade to mediate the transcription of downstream genes that regulate stress tolerance $[4,5]$. Genetic studies have revealed that the loss of function of genes involved in ABA metabolism or signaling affects plant developmental processes and leads to a decrease in stress tolerance [6,7]. The role of $\mathrm{ABA}$ in regulating plant development and stress response also involves its crosstalk with other phytohormones and signaling molecules such as glutathione (GSH) $[8,9]$.

Glutathione is a water-soluble low molecular weight non-protein tripeptide ( $\gamma$-glutamylcysteinyl-glycine) that serves as the most abundant thiol source in plant cells [10]. It is involved in several plant growth and developmental processes including regulation of cellular redox homeostasis and gene expression, and plant response to biotic and abiotic stress factors [11-13]. One of the major functions of GSH is detoxification of excess reactive oxygen species (ROS) produced by cellular processes under stress conditions [14,15]. 
As an antioxidant, GSH is a key component of the major $\mathrm{H}_{2} \mathrm{O}_{2}$ scavenging ascorbateglutathione (AsA-GSH) metabolic pathway, acting as reducing agent to regenerate reduced ascorbate from its oxidized form via a reaction catalyzed by dehydroascorbate reductase (DHAR) [16]. Furthermore, GSH is involved in ROS removal by acting as a substrate in metabolic reactions catalyzed by glutathione-S-transferases (GST) and glutathione peroxidases (GPX) [15]. Under normal/non-stress conditions, plants maintain a relatively high cellular level ratio of reduced GSH to its oxidized form GSSG (GSH/GSSG) at a cellular level, however, under stress conditions, GSH is actively involved in antioxidant defense responses and it is converted to its oxidized form, GSSG. Previous studies have shown that intracellular GSH/GSSG ratio triggers signal transductions mediating plant response to stress factors and acts as a marker of intracellular redox homeostasis $[17,18]$. In support of this, several studies have demonstrated the role of GSH in enhancing plant tolerance to a variety of abiotic stressors including drought, cold, salinity, high temperature and metal toxicity [19-21]. Plant hormones such as ABA are implicated in modulating the intracellular GSH/GSSG ratios under abiotic stress conditions [22,23]. For example, exogenous ABA has been shown to increase the ratio of GSH/GSSG levels in tomato plants [24]. Furthermore, ABA has been shown to lead to differential alteration of the GSH/GSSG ratios in two maize lines with varying degree of tolerance to osmotic and drought stress [25]. GSH is also involved in post-translational modification of proteins through S-glutathionylation and S-nitrosoglutathione (GSNO)-mediated S-nitrosylation, and these protein modifications modulate signaling events and thereby influence plant developmental processes and response to stress factors [23].

The roles of ABA or GSH in either plant development or stress response have been reviewed extensively; however, literature on the role of coordinated interplay between $\mathrm{ABA}$ and GSH in regulating both plant developmental processes and plant-environment interactions are scarce. This review highlights the current knowledge on the role of crosstalk between GSH and ABA signaling in regulating plant development and stress response with emphasis on seed dormancy, germination, stomatal closure and drought tolerance.

\section{Abscisic Acid Metabolism and Signaling}

\subsection{Abscisic Acid Metabolism}

ABA in plants is synthesised from zeaxanthin through several enzymatic reactions [26]. Zeaxanthin $\left(\mathrm{C}_{40}\right)$ is first converted to xanthoxin $\left(\mathrm{C}_{15}\right)$ by the actions of zeaxanthin epoxidase (ZEP) and 9-cis-epoxycarotenoid dioxygenase (NCED). The NCED-mediated reaction, which involves a non-reversible oxidative cleavage of 9-cis-violaxanthin and/or 9-cisneoxanthin to xanthoxin, is considered the rate-limiting step in ABA biosynthesis. Xanthoxin dehydrogenase converts xanthoxin to abscisic aldehyde, which is further oxidized to ABA by the action of abscisic aldehyde oxidase (AAO).

ABA catabolism also plays an important role in regulating ABA levels in plant tissues. ABA catabolism involves two types of reactions, namely hydroxylation and conjugation [26]. The main hydroxylation reaction of ABA catabolism involves the conversion of $\mathrm{ABA}$ to phaseic acid through hydroxylation of the $\mathrm{C}-8^{\prime}$ methyl group of the ABA ring structure by the action of ABA 8'-hydroxylase, which is encoded by CYP707As genes. ABA catabolism by conjugation involves the formation of ABA-glucosyl ester (ABA-GE) by the action of UDP-glucosyltransferase. Upon cellular demands, inactive ABA-GEs can be rapidly converted to active ABA by ABA-GE hydrolyzing enzymes, beta-glycosidases [27].

\subsection{ABA Signaling}

ABA signaling in plants involves three core components, namely, pyrabactin resistance (PYR)/pyrabactin resistance-like (PYL)/regulatory component of ABA receptors (RCAR) (PYR/PYL/RCAR), type $2 \mathrm{C}$ protein phosphatases (PP2Cs), which act as negative regulators of ABA signaling, and sucrose non-fermenting-1-(SNF1)-related protein kinase 2 (SnRK2) that acts as a positive regulator of ABA signaling [28,29]. In the absence of ABA, PP2Cs bind to and inactivates $S n R K 2$, thereby inhibiting ABA signaling; however, in the presence 
of ABA, the PYR/PYL/RCAR forms a complex with PP2Cs, leading to inhibition of PP2Cs activity and thereby activating SnRK2 [30]. The activated SnRK2 phosphorylates thereby activates the downstream transcription factors including the ABA insensitive 3 ( $A B I 3), A B I 4$ and $A B I 5$ that belong to the $\mathrm{B} 3, \mathrm{AP} 2$ and basic leucine zipper-(bZIP) domain transcription factor families, respectively, which regulate the expression of ABA responsive genes.

\section{Glutathione Biosynthesis and Metabolism}

The synthesis of GSH from its constituent amino acids, which include glutamate, L-cysteine and glycine, involves two ATP-dependant enzymatic reactions mediated by $\gamma$ glutamylcysteine synthetase ( $\gamma$-ECS or GSH1) and GSH synthetase (GS or GSH2) [31]. The $\gamma$-ECS enzyme catalyzes the first and rate-limiting step to produce $\gamma$-glutamylcysteine $(\gamma$ EC) from the L-glutamate and L-cysteine amino acids. In the second step, GSH synthetase catalyzes the addition of glycine to $\gamma$-glutamylcysteine $(\gamma$-EC) to produce GSH. The reaction catalyzed by $\gamma$-ECS/GSH1 is considered as the rate-limiting step of GSH synthesis, and the activity of this enzyme is regulated by cellular levels of cysteine and glutamic acid and feedback inhibition by $\gamma$-EC and GSH [32].

GSH1 is localized only in the plastids while GSH2 is localized in the plastids and the cytosol, and both GSH1 and GSH2 are encoded by a single gene [33] (Figure 1). Consistent with the localization of GSH1, the first step of GSH synthesis occurs in the plastids; however, since the most abundant transcript of the multiple GSH2 transcript populations encodes a cytosolic GSH2, the second step is reported to occur most likely in the cytosol [15]. After its synthesis in the cytosol, GSH can be transported to other cellular compartments, predominantly in its reduced form or conjugated forms [34]. The reduced GSH can rapidly be converted to its oxidized form, GSSG, in various biochemical reactions, and the cellular homeostasis of GSH/GSSG ratio is maintained by the actions of glutathione reductase (GR) and GPX [35]. Deficiency in the activity of either GSH1 or GSH2 impairs GSH production and thereby negatively affects plant growth and development. For example, the Arabidopsis GSH1 knockout mutants, gsh1 and rml1 (root meristem less 1), are characterized by low GSH content, poor postembryonic root development and embryo death [36-38]. Several factors including the concentrations of cysteine and glycine, availability of ATP, photosynthetically active photon flux and enzymes that consume GSH also regulate the biosynthesis of GSH $[15,39]$. GSH, once produced, can also be subjected to conjugation with toxic xenobiotic substances by the action of GST [40] or can serve as a substrate for S-glutathionylation of proteins in the presence of small redox enzyme glutaredoxins (GRX), which also uses GSH as a cofactor (Figure 1). GSH can also react with NO free radical to produce GSNO, which nitrosylates target proteins. 


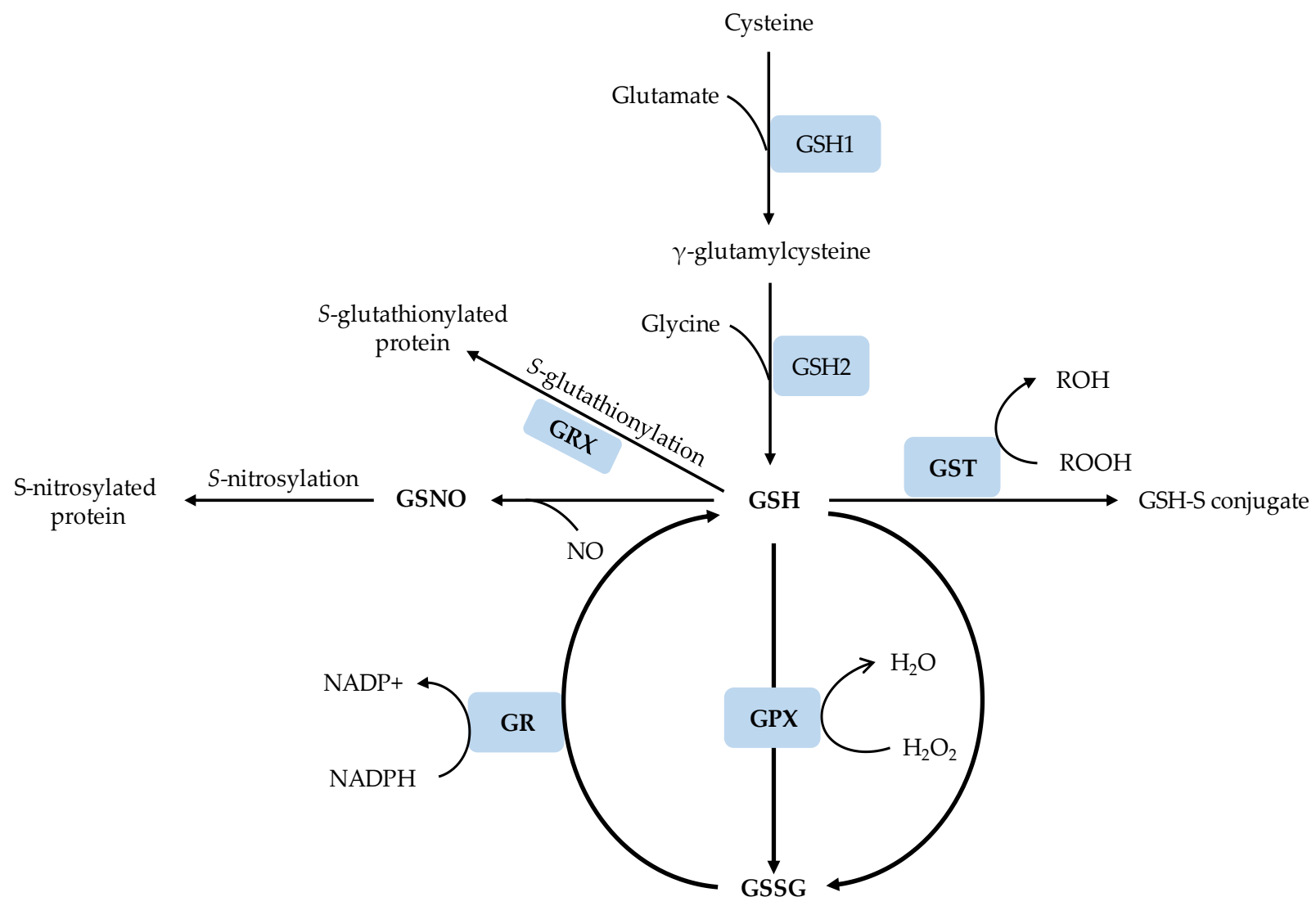

Figure 1. A schematic representation of GSH biosynthesis and metabolism. GSH1, $\gamma$-glutamylcysteine synthetase; GSH2, GSH synthetase; GSH, reduced glutathione; GSSG; oxidized glutathione; GST, glutathione-S-transferases; GPX, glutathione peroxidase; GRX, glutaredoxin; GR, glutathione reductase; GSNO, S-nitrosoglutathione.

\section{Glutathione Modulates ABA Signaling in the Regulation of Seed Dormancy and Germination}

Seed dormancy and germination are important developmental processes that are regulated by several signaling pathways [41]. Plant hormones, mainly ABA and gibberellin (GA), play central roles in regulating the induction, maintenance and release of seed dormancy and seed germination [29]. Other signal compounds including ROS, such as $\mathrm{H}_{2} \mathrm{O}_{2}$, are also implicated in the control of these developmental events via regulating ABA-GA balance [42,43]. However, excess production of ROS can lead to oxidative stress that negatively affects plant growth and developmental processes. Thus, activation of antioxidant systems to scavenge the excessive ROS molecules is crucial to mitigate the negative effects.

Glutathione is one of the most important components of antioxidant systems that scavenge excessive ROS molecules. Owing to this role, GSH could play a role in the control of seed dormancy and germination. It has been shown previously that GSH breaks seed dormancy in barley, and dormancy breakage by $\mathrm{H}_{2} \mathrm{O}_{2}$ was shown to be associated with enhanced GSH level [44]. Similarly, treatment of recalcitrant seeds of silver maple with GSH has been shown to decrease the rate of dehydration and stimulate germination [45]. This was associated with a higher level of $\mathrm{H}_{2} \mathrm{O}_{2}$, which is proposed to have a signaling function to help the seeds cope with water stress associated with the dehydration process instead of acting as an indicator of severe oxidative stress and enhanced AsA-GSH cycling [45]. Previous studies have shown that enzymes which regulate the GSH pool have a significant effect on ABA signaling and the regulation of seed germination and dormancy. For example, genes encoding GPX and GST enzymes, which modulate cellular GSH levels, have been shown to play roles in regulating ABA signaling in arresting seed 
germination [46-49]. However, an increase in the levels of GSH-containing glutathionylated proteins/compounds such as GRX and GSNO have been shown to suppress ABA signaling during seed germination $[50,51]$.

4.1. Glutathione Peroxidase and Glutathione S-Transferase as Regulators of GSH Pool and ABA Signaling in the Control of Seed Dormancy and Germination

Glutathione peroxidase is an antioxidant enzyme that protects plants from oxidative stress via reducing lipid peroxides and free $\mathrm{H}_{2} \mathrm{O}_{2}$ to their corresponding alcohols and water by utilizing GSH [52]. GPX also plays an important role in regulating ABA signaling [46,49]. It has been shown previously that the Arabidopsis GPX loss of function mutants gpx3-1 and $g p x 3-2$, which lack GPX activity, are insensitive to ABA during seed germination. This role of GPX in regulating ABA response is mediated by its modulation of the activity of ABI proteins, mainly ABI2 that acts as a negative regulator of ABA signaling [46]. Furthermore, seeds from GPX3 silenced rice plants (gpx3i) are insensitive to ABA and showed germination in the presence of $\mathrm{ABA}$, while germination of seeds from the corresponding wild-type/control plants was completely inhibited by ABA [49]. The gpx3i mutant plants are also characterized by the prevalence of enhanced glutathionylation, repressions of proteins involved in epigenetic regulation and ubiquitination, and upregulation of the PP2C protein [49]. In contrast, ectopic expression of the putative wheat GPX genes, designated as W69 and W102, in Arabidopsis has been reported to exhibit reduced seed sensitivity to $\mathrm{ABA}$ and enhanced germination under high salt stress [53]. Possible reasons for this contradictory result include differences in the concentration of exogenous $\mathrm{ABA}$, plant growth conditions, type of GPX gene homologs and the plant species considered in the respective studies. These results therefore highlight the multifunctionality of GPX isoenzymes that are known to have distinct subcellular locations; their genes exhibit distinct expression patterns in response to different environmental factors or in different plant species [52]. However, alterations in the expression levels of the ABA signaling genes $A B I 1$ and $A B I 2$ and the ROS biosynthesis gene RbohD in GPX overexpressing transgenic plants, and induction of PP2C protein in GPX3 silenced plants along with the observation of physical interaction between GPX and ABI proteins, highlight the role of GPX in modulating ABA signaling and thereby seed dormancy and germination.

Glutathione S-transferase is a ubiquitous protein that decreases the GSH pool via catalysing the conjugation of GSH to various xenobiotics to detoxify such compounds, which accumulate as a result of oxidative stress, and thereby maintain cellular redox homeostasis [40]. Therefore, GSTs affect a range of redox-dependent cellular processes that involve hormone and stress responses including ROS-mediated ABA metabolism and signaling. Consistently, the gstu7 and gstu17 mutants of Arabidopsis have been reported to exhibit increased GSH and ABA levels and decreased $\mathrm{H}_{2} \mathrm{O}_{2}$ levels, and the seeds of these mutants are found to be less sensitive to ABA during germination [47,48]. Furthermore, the gstu7 mutant shows reduction in the expression levels of genes encoding proteins that act as positive regulators of ABA signaling including SnRK, $A B I 3$ and $A B I 5$ [48]. In contrast, overexpression of GSTU19 has been shown to lead to induction of germination under drought conditions and this effect is associated with increased levels of proline and activities of antioxidant enzymes [54]. Similarly, ectopic expression of the rice GSTU4 gene in Arabidopsis has been reported to lead to enhanced seed germination under salinity and oxidative stress conditions [55]. The same authors also showed that the transgenic Arabidopsis plants expressing rice GSTU4 exhibit reduced ABA sensitivity and ROS levels. Seeds of Arabidopsis plants expressing the GST gene of Tamarix hispida (GSTZ1) are also shown to be less sensitive to ABA during germination [56]. These results imply the importance of GSH-ROS homeostasis in ABA-mediated regulation of seed dormancy and germination. 


\subsection{Glutathione-Mediated Post-Translational Control of ABA Signaling, and Seed Dormancy and Germination}

Glutaredoxins are thiol-disulfide oxidoreductases (thioltransferases) that use the reducing power of GSH to catalyse the reversible reduction of disulfide bonds of substrate proteins, leading to their post-translational modification. They also function in scavenging cellular ROS and regulating redox homeostasis [57,58]. Genetic studies that involved overexpression or silencing of the GRX genes have demonstrated their importance in the regulation of plant oxidative stress responses [51,59]. Glutaredoxins have been implicated as negative regulators of ABA signaling during seed germination/preharvest sprouting $[51,59,60]$. The rice PHS9 gene encodes a unique CC-type GRX that interacts with putative GTPase activating protein (GAP), which is an interacting partner of the ABA receptor RCAR1, and overexpression of either PHS9 or GAP has been shown to lead to reduced ABA sensitivity during seed germination [51]. Similarly, seeds of Arabidopsis plants expressing the cassava gene encoding the CC-type GRX-C15 (designated as GRXC15) have been shown to exhibit enhanced germination in the presence of ABA, indicating decreased seed sensitivity to ABA [59]. Consistently, silencing of the GRXS17 gene in rice leads to seed hypersensitivity to $\mathrm{ABA}$ and thereby the inhibition of germination; however, the germination inhibitory effect of ABA can be reversed by GSH [60]. Since glutaredoxins are known to be important components in maintaining redox-dependent signaling [61], it is likely that silencing GRXS17 leads to increase in the accumulation of $\mathrm{H}_{2} \mathrm{O}_{2}$, which is known to positively regulate $\mathrm{ABA}$ signaling and thereby inhibit seed germination. In agreement with this, accumulation of $\mathrm{H}_{2} \mathrm{O}_{2}$ was prevalent in the root tips of GRXS17-silenced rice seedlings [60].

Previous studies have shown that the role of $\mathrm{NO}$ in promoting seed germination is associated with negative regulation of ABA signaling via inhibition of SnRK and Snitrosylation-mediated degradation of ABI5 [50,62]. Furthermore, NO has been shown to break seed dormancy through inducing the expression levels of ABA catabolic gene CYP707A2 and thereby reducing ABA level [63]. GSH plays a critical role in the regulation of NO signaling as it reacts with NO and forms GSNO [64], an important mobile cellular NO that triggers NO signal transduction [65]. Consistently, dormancy release in response to the cold stratification of apple seeds has been reported to be associated with enhanced levels of GSNO and GSH [66]. These reports highlight the significance of GSH in mediating NO and ABA cross-signaling in the regulation of seed dormancy and germination, although further studies are required to elucidate such functionality of GSH and the associated underlying mechanisms. The role of GSH in mediating ABA signaling in the control of seed dormancy and germination is depicted by a model shown in Figure 2. 


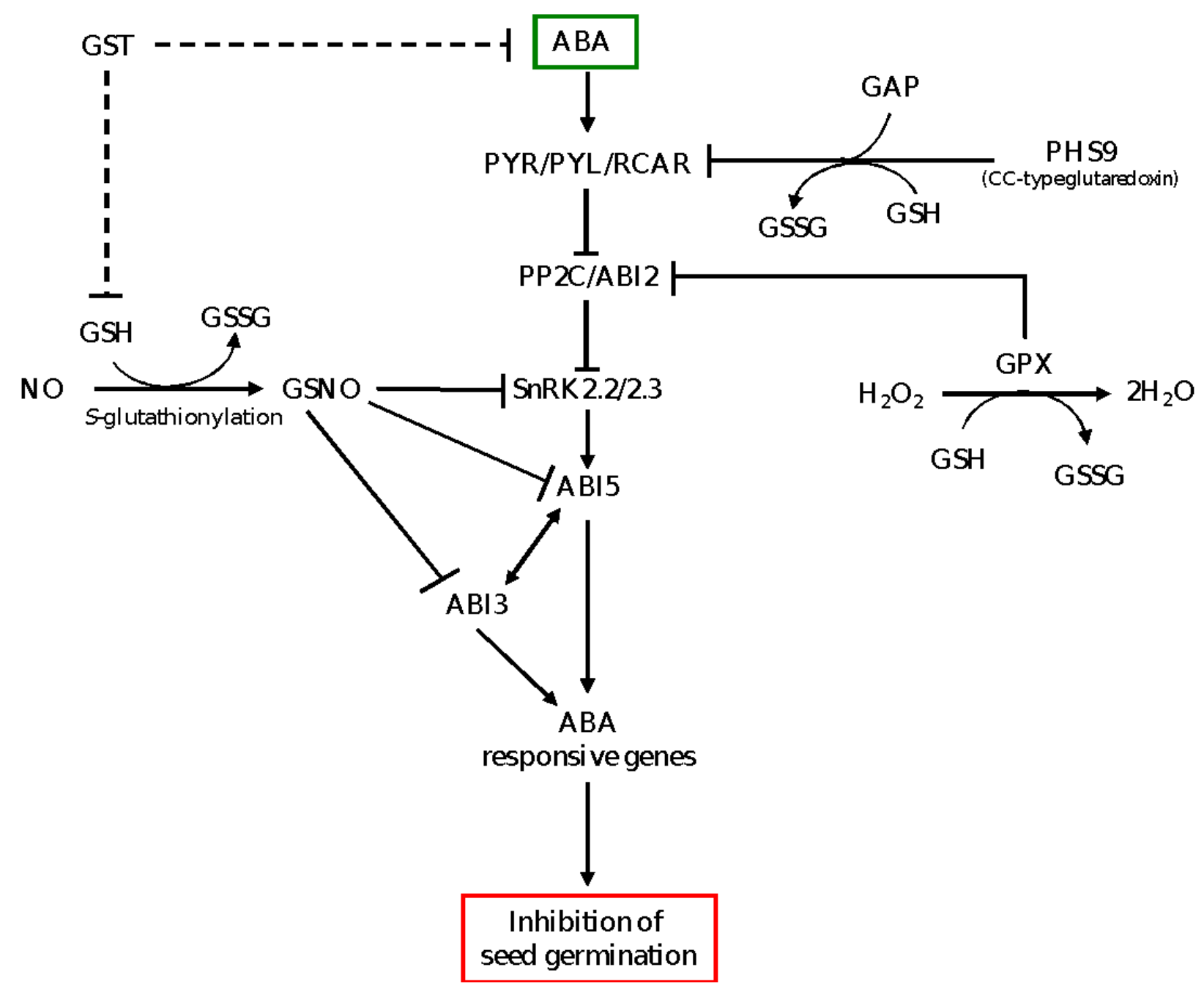

Figure 2. A model depicting GSH-mediated ABA signaling in the control of seed dormancy and germination. GSH in the presence of NO forms GSNO, which inhibits SnRK2.2/2.3 and ABI5 proteins of ABA signaling through S-nitrosylation, leading to repression of ABA signaling and promotion of seed germination. The CC-type glutaredoxin (PHS9) interacts with putative GTPase activating protein (GAP), which acts as an interacting partner of RCAR and inhibits PYR/PYL/RCAR, thereby repressing ABA signaling and enhancing seed germination. The GPX, which acts as antioxidant enzyme in maintenance of $\mathrm{H}_{2} \mathrm{O}_{2}$ homeostasis, physically interacts with and inhibits $\mathrm{ABI}$, a negative regulator of $\mathrm{ABA}$ signaling, leading to activation of ABA signaling and inhibition of seed germination. GST is proposed to reduce the levels of ABA and GSH (broken lines); GSH suppresses the expression of ABA signaling genes and therefore induces seed germination. PYR/PYL/RCAR, pyrabactin resistance/pyrabactin resistance-like/regulatory component of ABA receptors; PP2C, type 2C protein phosphatase; SnRK, sucrose non-fermenting-1-related protein kinase; ABI2/3/5, ABA insensitive 2/3/5; NO, nitric oxide; GSNO, S-nitrosoglutathione; GST, glutathione S transferase; GPX, glutathione peroxidase; GSH, reduced glutathione; GSSG, oxidized glutathione.

\section{Glutathione and ABA-Induced Stomatal Closure}

\subsection{Modulation of Glutathione Level and Its Role in ABA-Mediated Stomatal Closure}

Stomata, small pores on the epidermis of the leaf, regulate transpiration, photosynthetic gas exchange and microbial entry. Stomatal closure represents the initial defense response of plants to biotic and abiotic stresses, for example, to restrict microbial entry or water loss. Stomatal guard cells are able to sense and respond to external stimuli and thereby quickly regulate stomatal aperture [67]. Several plant hormones are known to influence stomatal closure in order to reduce transpirational water loss under water deficit/drought conditions. However, the plant hormone ABA acts as a major regulator of 
this event by involving other signaling components such as ROS, NO, reactive carbonyl species (RCS) and $\mathrm{Ca}^{2+}$ in the guard cells $[67,68]$.

Previous studies hasis chlorinal-1 (ch1-1) mutant, which is deficient in light-harvesting complex proteins in photosystem II, exhibits reduced levels of GSH in the guard cells $[69,70]$. While stomatal closure in the ch1-1 mutant is enhanced by exogenous ABA, treatment with exogenous GSH leads to inhibition of stomatal closure even after ABA treatment [69]. These results suggest that a decrease in GSH level in the guard cells promotes ABA-mediated stomatal closure. However, GSH appears not to affect ABA-induced ROS production since treatment of the ch1-1 mutant with exogenous GSH donor does not have significant effect on ABA-induced production of ROS. Similarly, cad2-1 mutant of Arabidopsis, which is defective in $\gamma$-ECS activity, exhibits a reduced level of GSH in the guard cells and thereby induction of ABA-mediated stomatal closure [8]. However, a recent report has shown that stomatal closure in the cad2-1 mutant is not associated with reduction in GSH level, but rather with accumulation of cysteine, a precursor of GSH [71]. Cysteine is the product of the sulfate assimilatory pathway, and previous reports have provided insights into the role of sulfur assimilation into cysteine in regulating ABA level and signaling, and thereby stomatal closure [71,72]. Previous studies have implicated that cysteine induces transcriptional activation of NCED3 and also serves as a source of sulfur for molybdenum cofactor (MoCo) sulfurylase (ABA3)-mediated production of sulfurylated form of (MoCo), which is crucial for the activation of the ABA biosynthesis enzyme AAO3, leading to enhanced ABA biosynthesis [71,73]. Furthermore, ABI1 and SnRK have been implicated as critical ABA signaling components in mediating cysteine-induced stomatal closure [72]. Therefore, a decrease in GSH synthesis in the guard cells leads to cysteine accumulation, which in turn activates ABA biosynthesis and signaling, and therefore stomatal closure.

Other evidence that supports the induction of stomatal closure in response to a decrease in GSH level comes from studies that involve the use of chemicals that deplete the GSH level such as iodomethane, p-nitrobenzyl chloride and ethacrynic acid. Exogenous applications of such chemicals to excised leaves of Arabidopsis have been shown to reduce intracellular GSH levels in the guard cells [74]. This is shown to be associated with the prevalence of enhanced ABA-induced stomatal closure without any change in the cytosolic alkalization, cytosolic $\mathrm{Ca}^{2+}$ oscillation and ROS production in the guard cells [74]. It is therefore likely that the role of GSH in the guard cells in regulating stomatal closure is not associated with the scavenging of ABA-induced ROS accumulation but is via its effect on ABA signaling components downstream of ROS generation. Overall, these reports indicate the role of modulation of GSH level in the regulation of ABA-mediated stomatal closure and therefore tolerance to drought.

\subsection{Glutathione Peroxidase as a Regulator of GSH Pool and ABA-Induced Stomatal Closure}

It has been reported that $\mathrm{H}_{2} \mathrm{O}_{2}$ plays a key role in ABA-induced stomatal closure through affecting the $\mathrm{Ca}^{2+}$ channels in the guard cells [75]. ABA signaling involves the binding of ABA to the PYR/PYL/RCAR receptor, which in turn interacts with PP2Cs that act as negative regulators of $\mathrm{ABA}$ signaling and thereby regulate the downstream components [76]. Mutation in $A B I 1$ disrupts ABA signaling upstream of $\mathrm{H}_{2} \mathrm{O}_{2}$ synthesis, whereas mutation in $A B I 2$ impairs signaling downstream of $\mathrm{H}_{2} \mathrm{O}_{2}$ production in the guard cells [77]. Previous study has shown that ABA-induced stomatal closure is regulated by GPX, an antioxidant enzyme that catalyzes the reduction of $\mathrm{H}_{2} \mathrm{O}_{2}$ by using GSH as a substrate. GPX3, which functions as redox transducer in $\mathrm{H}_{2} \mathrm{O}_{2}$ signal transduction, interacts with ABI2 and thereby directly influences guard cell plasma membrane $\mathrm{Ca}^{2+}$ channels in regulating ABA-induced stomatal closure [46]. Consistently, the gpx3 mutant of Arabidopsis is less sensitive to $\mathrm{ABA}-$ and $\mathrm{H}_{2} \mathrm{O}_{2}$-induced stomatal closure [46]. Similarly, silencing of GPX3 in rice makes plants less sensitive to ABA-induced stomatal closure [49]. Proteomic studies have also revealed that silencing of GPX3 induces S-glutathionylation and inhibits protein ubiquitination [49]. The involvement of protein ubiquitination in ABA signaling is well established, for example, ABA signaling is activated by the degradation 
of ABI1, a negative regulator of ABA signaling, through the UBC27-AIRP3 ubiquitination complex [78]. In addition, the protein components involved in the ubiquitination and proteasome complex are reported to be S-glutathionylated at cysteine residues under stress conditions $[79,80]$. Overall, these reports indicate the significance of GSH redox pool in the guard cells of the stomata to the control of ABA-induced stomatal closure via post-translational modifications of ABA signaling components.

\section{Glutathione-Mediated ABA Signaling in Drought Tolerance}

ABA plays a critical role in regulating plant responses to various unfavorable environmental conditions including drought stress [81]. An increase in ABA level in response to abiotic stress factors such as drought has been reported in many plant species [82]. In agreement with this, exogenous ABA or genetic mutations that lead to an increase in ABA level and signaling have been shown to improve the performance of plants under drought conditions. For example, treatment of plants with exogenous ABA or its synthetic analogues enhances drought tolerance in several species including wheat [83-85], barley [86], rice [87], sugarcane [88] and tea [89]. Furthermore, overexpression of the ABA biosynthetic gene NCED in tomato [90], tobacco, [91] and Petunia [92], and the ABA signaling gene PYL in rice [93] and tomato [94] results in improved tolerance to drought.

Tolerance of plants to drought and other abiotic stress factors is also mediated by other mechanisms such as those involving antioxidant defence systems that mitigate droughtinduced oxidative stress. Plants exposed to abiotic stress factors such as drought generate excessive ROS, and this ROS is subjected to detoxification either through the enzymatic or non-enzymatic antioxidant systems. With respect to the non-enzymatic antioxidant system, the AsA-GSH pathway plays a central role in ROS scavenging. Previous studies have revealed a close relationship between ABA and GSH in mediating plant response to drought stress; early accumulation of ABA stimulates ROS production, which in turn enhances the expression level of several genes involved in the AsA-GSH pathway and GSH content to counter stress-induced oxidative stress [84]. It has been shown previously that the levels of non-enzymatic antioxidants such as GSH and ascorbate increases in response to drought in many plant species [84,95]. Furthermore, exogenous application of ABA, for example in wheat, maize and soybean, leads to upregulation of genes involved in GSH synthesis and/or an increase in GSH level, resulting in an enhanced tolerance to drought $[84,96,97]$. Conversely, treatment with exogenous GSH or overexpression of the GSH biosynthesis gene GSH1 in Arabidopsis improves drought tolerance through altering the expression patterns of ABA metabolic and signaling genes, leading to upregulation of the downstream ABA responsive genes [12,47]. Despite these reports, the mechanisms underlying the interaction between GSH and ABA in regulating plant response to drought remain to be elucidated.

\subsection{Glutathione Peroxidase and Glutathione S-Transferases as Regulators of GSH Pool and Drought-Induced ABA Signaling}

Previous studies have provided insight into the roles of different enzymes such as GPX and GST that regulate GSH homeostasis in the regulation of ABA signaling and drought tolerance [21,46]. Loss of function mutation in GPX3 of Arabidopsis results in an increase in $\mathrm{H}_{2} \mathrm{O}_{2}$ levels, interruption of ABA-activated calcium channels and repression of ABA and stress responsive genes, leading to increased sensitivity to drought, while overexpression of GPX3 enhances tolerance to drought stress [46]. Consistently, the same authors have shown that GPX interacts with ABI proteins, highlighting its importance in mediating ABA and drought signaling. In addition, ectopic expression of GPX of Rhodiola crenulata (GPX5) in Salvia miltiorrhiza plants resulted in increased drought tolerance through enhancing GSH content and expression of ABA-signaling genes [21]. These reports suggest dual roles of GPX in $\mathrm{H}_{2} \mathrm{O}_{2}$ homeostasis; in scavenging $\mathrm{H}_{2} \mathrm{O}_{2}$ and regulating the use of $\mathrm{H}_{2} \mathrm{O}_{2}$ as an oxidative signal transducer in the modulation of ABA and drought stress signaling.

Drought stress has been shown to induce the expression level of genes encoding GST and activity of the corresponding enzyme in several plant species [98,99]. Furthermore, 
ectopic expression of the rice GSTU4 and GSTU30 genes in Arabidopsis confers tolerance to drought and oxidative stress. These effects are closely associated with lower accumulation of ROS, upregulation of ABA responsive genes, including $A B I 3, A B I 5, C H Y R 1$ and $R A B 18$, that are known to have roles in plant response to drought stress, and decreased sensitivity to exogenous ABA $[55,99]$. These results suggest the role of GSTU genes in mediating the ABA-dependent oxidative and drought stress tolerance. In contrast, the Arabidopsis GSTU17 has been shown to function as a negative regulator of drought-mediated signal transduction pathways; the gstu17 mutant exhibits increased GSH and ABA levels, reduced stomatal aperture and transpirational water loss rates, leading to enhanced tolerance to drought [47]. Given that GST, which is encoded by large gene families, has multiple functions [100], its role in ABA-mediated drought stress signaling might vary with plant species.

\subsection{Glutathione-Mediated Post-Translational Control of ABA Signaling in Drought Tolerance}

$S$-glutathionylation is a reversible redox-sensitive post-translational modification that adds GSH to cysteine residues of proteins and thereby modulates their functions [101]. This protein modification mechanism occurs especially under increased production of ROS and/or GSSG. Among the stress-related plant proteins that undergo S-glutathionylation are annexins, multi-functional calcium-dependent membrane binding proteins that serve as important components in calcium signaling pathways [102]. Overexpression of annexin genes in different plant species has been shown to enhance drought tolerance, and this effect is closely associated with reduced accumulation of ROS, increased ABA content and sensitivity, and thereby enhanced stomatal closure and reduced transpirational water loss [103-105]. Studies in Arabidopsis have revealed that S-glutathionylation of the cysteine residues in the AnnAt1 protein occurs in response to ABA treatment, and glutathionylation modification of AnnAt1 reduces its calcium-binding activity [103], which might affect its ability to form $\mathrm{Ca}^{2+}$ channels in biomembranes and thereby ABA-dependent drought signaling. Given that GSH regulates calcium influx [106,107], it is likely that GSH is involved in regulating drought tolerance through $S$-glutathionylation of proteins that mediate ABA-dependent drought signaling.

A recent study has shown the significance of sulphur in ABA-mediated drought tolerance [71]. For example, maize roots accumulate high amounts of free sulphate, GSH and cysteine under drought conditions; accumulation of free sulphate promotes the synthesis and reduction of cysteine and induces the transcription of GSH1, which in turn improves the GSH redox state via increasing the total amount of GSH [108]. Previous studies have shown that loss of function mutation in chloroplast sulfate transporter $3 ; 1$, which is involved in sulfate transport into chloroplasts, leads to a decrease in cysteine level [109]. Given that cysteine activates the transcription of the ABA biosynthetic gene NCED3 and serves as a substrate for post-translational activation of the ABA biosynthesis enzyme $\mathrm{AAO} 3$ via MoCo sulfurylase ABA3, reduction in its level leads to inhibition of ABA synthesis [71]. These findings reflect the significance of modulation of GSH level in regulating ABA and drought stress signaling via post-translational regulatory mechanisms. A model shown in Figure 3 depicts the role of GSH in mediating ABA signaling in the regulation of stomatal closure and drought tolerance. 


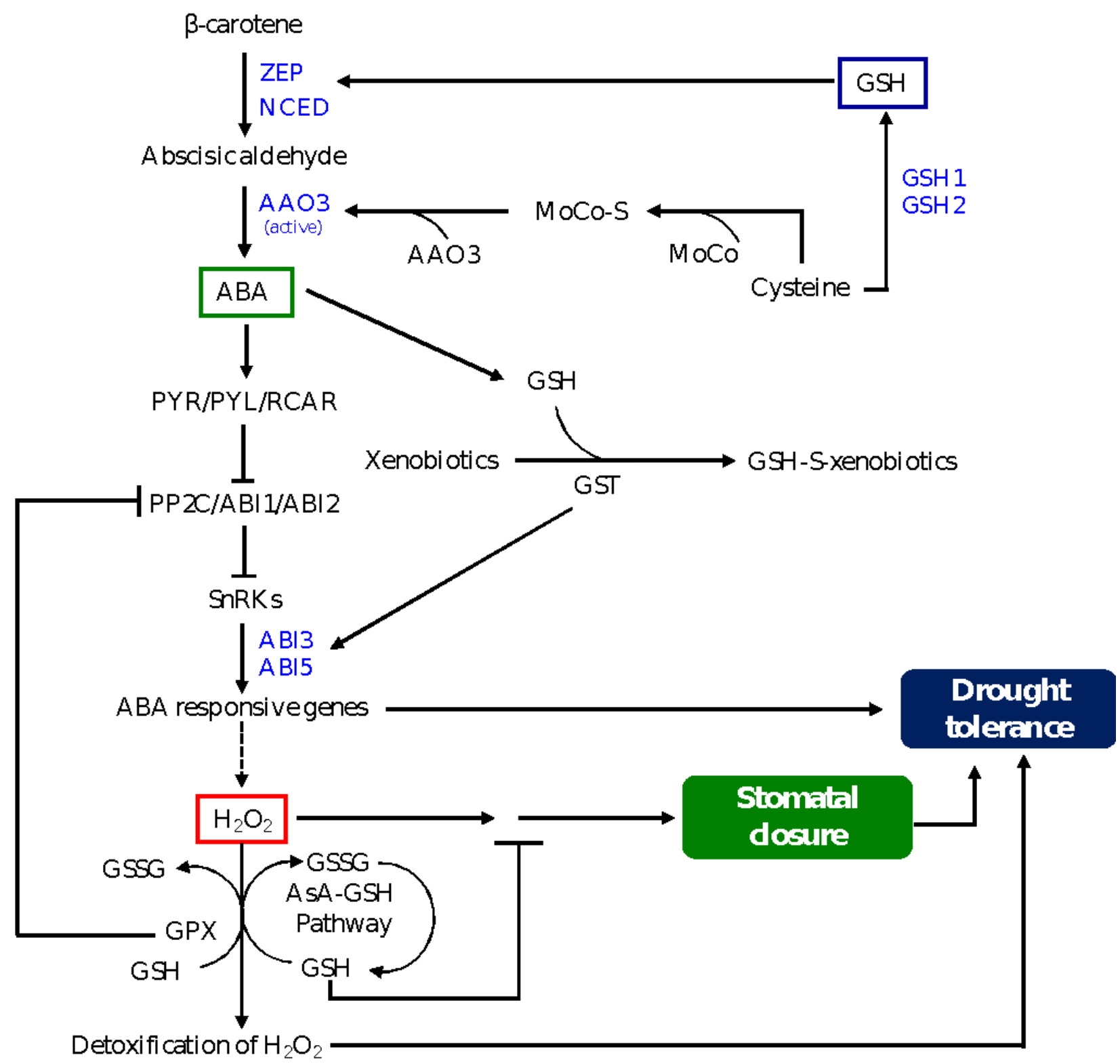

Figure 3. A model depicting GSH-mediated ABA signaling in stomatal closure and drought tolerance. Induction of GSH biosynthesis reduces the level of cysteine, which plays a role in activating the AAO3 enzyme and therefore ABA synthesis in the guard cells, leading to inhibition of ABA-induced stomatal closure. Whereas drought-induced GSH level enhances the expression levels of ZEP and NCED, resulting in an increase in ABA synthesis, GST detoxifies xenobiotic substances by conjugating them with GSH, leading to induction in the expression of genes encoding ABI3 and ABI5, transcription factors that directly activate the expression of ABA responsive genes and drought tolerance. GSH is involved in the regulation of the downstream signaling of $\mathrm{ABA}$-induced $\mathrm{H}_{2} \mathrm{O}_{2}$ in the guard cells and thereby preventing stomatal closure. GSH is also involved in the detoxification of $\mathrm{H}_{2} \mathrm{O}_{2}$ through the AsA-GSH pathway. The role of GPX is as described in Figure 2, and it promotes ABA-induced stomatal closure and drought tolerance via inhibiting ABI2, which acts as a negative regulator of ABA signaling. ABA signaling components are described in Figure 2. ZEP, zeaxanthin epoxidase; NCED, 9-cis-epoxycarotenoid dioxygenase; AAO3 abscisic aldehyde oxidase3; MoCo, molybdenum cofactor; MoCo-S, sulfurylated MoCo; AsA, ascorbate.

\section{Conclusions and Future Prospects}

Studies conducted to date have provided important insights into the role of GSH and ABA interplay at multiple levels of signaling cascades in the regulation of plant developmental events such as seed dormancy and germination, and their response to multiple environmental factors including drought. However, the molecular mechanisms 
underlying the role of GSH and ABA crosstalk in regulating these developmental and stress response events are still poorly understood. It is therefore necessary to identify the regulatory nodes that are central to ABA-GSH interaction in order to elucidate the hierarchy of the signal networks and understand the endogenous and exogenous cues that influence this hierarchy. Recent reports implicate GSH in the regulation of signaling pathways through modifying the respective protein components via $S$-glutathionylation and/or GSNO-mediated protein S-nitrosylation. Therefore, elucidating GSH-induced post-translational protein modifications of $\mathrm{ABA}$ and stress signaling components through biochemical, molecular and genetic studies will have paramount significance in enhancing our understanding of GSH-mediated regulation of ABA and stress signaling networks. Moreover, further studies are needed to identify the mechanisms underlying the synthesis, transport and degradation of GSNO and the roles of these processes in ABA-regulated plant developmental events and stress responses. GSH has also been implicated in the regulation of epigenetic mechanisms such as DNA and histone methylation that control transcriptional programs. Thus, exploring the role of GSH in epigenetic regulation of the expression of genes involved in the ABA and other signal transduction networks that control plant developmental processes such as seed dormancy, and plant response to stress factors such as drought, is essential to advance our knowledge on the topic.

Author Contributions: Conceptualization, B.T.A.; Investigation, Writing-Original Draft Preparation: M.K.K. and M.N.; Writing-Review \& Editing: B.T.A.; Funding Acquisition, B.T.A. All authors have read and agreed to the published version of the manuscript.

Funding: This work was supported by a grant from the Natural Sciences and Engineering Research Council of Canada to B.T.A.

Institutional Review Board Statement: Not applicable.

Informed Consent Statement: Not applicable.

Data Availability Statement: Not applicable.

Conflicts of Interest: The authors declare no conflict of interest.

\section{References}

1. Verma, V.; Ravindran, P.; Kumar, P.P. Plant hormone-mediated regulation of stress responses. BMC Plant Biol. 2016, 16, 1-10. [CrossRef]

2. Ku, Y.S.; Sintaha, M.; Cheung, M.Y.; Lam, H.M. Plant hormone signaling crosstalks between biotic and abiotic stress responses. Int. J. Mol. Sci. 2018, 19, 3206. [CrossRef] [PubMed]

3. Vishwakarma, K.; Upadhyay, N.; Kumar, N.; Yadav, G.; Singh, J.; Mishra, R.K.; Kumar, V.; Verma, R.; Upadhyay, R.G.; Pandey, M.; et al. Abscisic acid signaling and abiotic stress tolerance in plants: A review on current knowledge and future prospects. Front. Plant Sci. 2017, 8, 161. [CrossRef] [PubMed]

4. Huang, D.; Wu, W.; Abrams, S.R.; Cutler, A.J. The relationship of drought-related gene expression in Arabidopsis thaliana to hormonal and environmental factors. J. Exp. Bot. 2008, 59, 2991-3007. [CrossRef] [PubMed]

5. Soma, F.; Takahashi, F.; Yamaguchi-Shinozaki, K.; Shinozaki, K. Cellular phosphorylation signaling and gene gxpression in drought stress responses: ABA-dependent and ABA-independent regulatory systems. Plants 2021, 10, 756. [CrossRef] [PubMed]

6. Belin, C.; De Franco, P.O.; Bourbousse, C.; Chaignepain, S.; Schmitter, J.M.; Vavasseur, A.; Giraudat, J.; Barbier-Brygoo, H.; Thomine, S. Identification of features regulating OST1 kinase activity and OST1 function in guard cells. Plant Physiol. 2006, 141, 1316-1327. [CrossRef]

7. Fujii, H.; Zhu, J.K. Arabidopsis mutant deficient in 3 abscisic acid-activated protein kinases reveals critical roles in growth, reproduction, and stress. Proc. Natl. Acad. Sci. USA 2009, 106, 8380-8385. [CrossRef]

8. Okuma, E.; Jahan, M.S.; Munemasa, S.; Hossain, M.A.; Muroyama, D.; Islam, M.M.; Ogawa, K.; Watanabe-Sugimoto, M.; Nakamura, Y.; Shimoishi, Y.; et al. Negative regulation of abscisic acid-induced stomatal closure by glutathione in Arabidopsis. J. Plant Physiol. 2011, 168, 2048-2055. [CrossRef] [PubMed]

9. Sirko, A.; Wawrzy, A. Control of ABA signaling and crosstalk with other hormones by the selective degradation of pathway components. Int. J. Mol. Sci. 2021, 22, 4638. [CrossRef] [PubMed]

10. Foyer, C.H.; Noctor, G. Ascorbate and glutathione: The heart of the redox hub. Plant Physiol. 2011, 155, 2-18. [CrossRef]

11. May, M.J.; Vernoux, T.; Leaver, C.; Van Montagu, M.; Inze, D. Glutathione homeostasis in plants: Implications for environmental sensing and plant development. J. Exp. Bot. 1998, 49, 649-667. [CrossRef] 
12. Cheng, M.C.; Ko, K.; Chang, W.L.; Kuo, W.C.; Chen, G.H.; Lin, T.P. Increased glutathione contributes to stress tolerance and global translational changes in Arabidopsis. Plant J. 2015, 83, 926-939. [CrossRef]

13. Asgher, M.; Per, T.S.; Anjum, S.; Masood, A.; Verma, S.; Khan, N.A. Contribution of glutathione in heavy metal stress tolerance in plants. In Reactive Oxygen Species and Antioxidant Systems in Plants: Role and Regulation under Abiotic Stress, 1st ed.; Khan, M., Khan, N., Eds.; Springer: Singapore, 2017; pp. 297-313. [CrossRef]

14. Edreva, A. Generation and scavenging of reactive oxygen species in chloroplasts: A submolecular approach. Agric. Ecosyst. Environ. 2005, 106, 119-133. [CrossRef]

15. Noctor, G.; Mhamdi, A.; Chaouch, S.; Han, Y.; Neukermans, J.; Marquez-Garcia, B.; Queval, G.; Foyer, C.H. Glutathione in plants: An integrated overview. Plant. Cell Environ. 2012, 35, 454-484. [CrossRef] [PubMed]

16. Pandey, P.; Singh, J.; Achary, V.M.M.; Mallireddy Reddy, K. Redox homeostasis via gene families of ascorbate-glutathione pathway. Front. Environ. Sci. 2015, 3, 1-14. [CrossRef]

17. Tausz, M.; Šircelj, H.; Grill, D. The glutathione system as a stress marker in plant ecophysiology: Is a stress-response concept valid? J. Exp. Bot. 2004, 55, 1955-1962. [CrossRef] [PubMed]

18. Aquilano, K.; Baldelli, S.; Ciriolo, M.R. Glutathione: New roles in redox signalling for an old antioxidant. Front. Pharmacol. 2014, 5, 1-12. [CrossRef]

19. Zhu, Y.L.; Pilon-Smits, E.A.H.; Jouanin, L.; Terry, N. Overexpression of glutathione synthetase in Indian mustard enhances cadmium accumulation and tolerance. Plant Physiol. 1999, 119, 73-79. [CrossRef]

20. Cao, F.; Fu, M.; Wang, R.; Diaz-vivancos, P. Exogenous glutathione-mediated abiotic stress tolerance in plants. In Glutathione in Plant Growth, Development, and Stress Tolerance, 1st ed.; Hossain, M., Mostofa, M., Diaz-Vivancos, P., Burritt, D., Fujita, M., Tran, L.S., Eds.; Springer: Cham, Switzerland, 2017; pp. 171-194. [CrossRef]

21. Zhang, L.; Wu, M.; Teng, Y.; Jia, S.; Yu, D.; Wei, T.; Chen, C.; Song, W. Overexpression of the glutathione peroxidase 5 (RcGPX5) gene from Rhodiola crenulata increases drought tolerance in Salvia miltiorrhiza. Front. Plant Sci. 2019, 9, 1950. [CrossRef]

22. Ghanta, S.; Chattopadhyay, S. Glutathione as a signaling molecule: Another challenge to pathogens. Plant. Signal Behav. 2011, 6, 783-788. [CrossRef]

23. Hasanuzzaman, M.; Nahar, K.; Anee, T.I.; Fujita, M. Glutathione in plants: Biosynthesis and physiological role in environmental stress tolerance. Physiol. Mol. Biol. Plants 2017, 23, 249-268. [CrossRef] [PubMed]

24. Zhou, J.; Wang, J.; Li, X.; Xia, X.J.; Zhou, Y.H.; Shi, K.; Chen, Z.; Yu, J.Q. $\mathrm{H}_{2} \mathrm{O}_{2}$ mediates the crosstalk of brassinosteroid and abscisic acid in tomato responses to heat and oxidative stresses. J. Exp. Bot. 2014, 65, 4371-4383. [CrossRef] [PubMed]

25. Kellos, T.; Tímár, I.; Szilágyi, V.; Szalai, G.; Galiba, G.; Kocsy, G. Stress hormones and abiotic stresses have different effects on antioxidants in maize lines with different sensitivity. Plant. Biol. (Stuttg.) 2008, 5, 563-572. [CrossRef] [PubMed]

26. Nambara, E.; Marion-poll, A. Abscisic acid biosynthesis and catabolism. Annu. Rev. Plant Biol. 2005, 56, 165-185. [CrossRef] [PubMed]

27. Xu, Z.-Y.; Kim, S.Y.; Seo, M.; Bressan, R.A.; Yun, D.; Hwang, I. A Vacuolar b -glucosidase homolog that possesses glucoseconjugated abscisic acid hydrolyzing activity plays an important role in osmotic stress responses in Arabidopsis. Plant Cell 2012, 24, 2184-2199. [CrossRef] [PubMed]

28. Nambara, E.; Okamoto, M.; Tatematsu, K.; Yano, R.; Seo, M.; Kamiya, Y. Abscisic acid and the control of seed dormancy and germination. Seed Sci. Res. 2010, 20, 55-67. [CrossRef]

29. Tuan, P.A.; Kumar, R.; Rehal, P.K.; Toora, P.K.; Ayele, B.T. Molecular mechanisms underlying abscisic acid/gibberellin balance in the control of seed dormancy and germination in cereals. Front. Plant Sci. 2018, 9, 668. [CrossRef] [PubMed]

30. Finkelstein, R. Abscisic acid synthesis and response. In Arabidopsis Book; American Society of Plant Biologists: Rockville, MD, USA, 2013; Volume 11, p. e0166. [CrossRef]

31. Noctor, G.; Gomez, L.; Vanacker, H.; Foyer, C.H. Interactions between biosynthesis, compartmentation and transport in the control of glutathione homeostasis and signalling. J. Exp. Bot. 2002, 53, 1283-1304. [CrossRef]

32. Hernández, L.E.; SOBRINO-Plata, J.; Montero-Palmero, M.B.; Carrasco-Gil, S.; Flores-Cáceres, M.L.; Ortega-Villasante, C.; Escobar, C. Contribution of glutathione to the control of cellular redox homeostasis under toxic metal and metalloid stress. J. Exp. Bot. 2015, 66, 2901-2911. [CrossRef]

33. Wachter, A.; Wolf, S.; Steininger, H.; Bogs, J.; Rausch, T. Differential targeting of GSH1 and GSH2 is achieved by multiple transcription initiation: Implications for the compartmentation of glutathione biosynthesis in the Brassicaceae. Plant J. 2005, 41, 15-30. [CrossRef]

34. Noctor, G.; Cyr, R.D.S.; Foyer, C.H. Ascorbate and glutathione: Keeping active oxygen under control. Annu. Rev. Plant Physiol. Plant Mol. Biol. 1998, 49, 249-279. [CrossRef]

35. Mahmood, Q.; Ahmad, R.; Kwak, S.; Rashid, A.; Anjum, N.A. Ascorbate and glutathione: Protectors of plants in oxidative stress. In Ascorbate-Glutathione Pathway and Stress Tolerance in Plants, 1st ed.; Anjum, N., Umar, S., Chan, M., Eds.; Springer: Dordrecht, The Netherlands, 2010; pp. 209-229. [CrossRef]

36. Vernoux, T.; Wilson, R.C.; Seeley, K.A.; Reichheld, J.; Muroy, S.; Brown, S.; Maughan, S.C.; Cobbett, C.S.; Van Montagu, M.; Inzé, D.; et al. The ROOT MERISTEMLESS1/CADMIUM SENSITIVE2 gene defines a glutathione-dependent pathway involved in initiation and maintenance of cell division during post-embryonic root development. Curr. Opin. Plant Biol. 2000, 3, 97-110. [CrossRef] 
37. Cairns, N.G.; Pasternak, M.; Wachter, A.; Cobbett, C.S.; Meyer, A.J. Maturation of Arabidopsis seeds is dependent on glutathione biosynthesis within the embryo. Plant Physiol. 2006, 141, 446-455. [CrossRef] [PubMed]

38. Pasternak, M.; Lim, B.; Wirtz, M.; Hell, R.; Cobbett, C.S.; Meyer, A.J. Restricting glutathione biosynthesis to the cytosol is sufficient for normal plant development. Plant J. 2008, 53, 999-1012. [CrossRef]

39. Ogawa, K.; Hatano-Iwasaki, A.; Yanagida, M.; Iwabuchi, M. Level of glutathione is regulated by ATP-dependent ligation of glutamate and cysteine through photosynthesis in Arabidopsis thaliana: Mechanism of strong interaction of light intensity with flowering. Plant. Cell Physiol. 2004, 45, 1-8. [CrossRef]

40. Shu, K.; Liu, X.D.; Xie, Q.; He, Z.H. Two faces of one seed: Hormonal regulation of dormancy and germination. Mol. Plant 2016, 9, 34-45. [CrossRef]

41. Liu, Y.; Ye, N.; Liu, R.; Chen, M.; Zhang, J. $\mathrm{H}_{2} \mathrm{O}_{2}$ mediates the regulation of ABA catabolism and GA biosynthesis in Arabidopsis seed dormancy and germination. J. Exp. Bot. 2010, 61, 2979-2990. [CrossRef]

42. Ishibashi, Y.; Kasa, S.; Sakamoto, M.; Aoki, N.; Kai, K.; Yuasa, T.; Hanada, A.; Yamaguchi, S.; Iwaya-Inoue, M. A role for reactive oxygen species produced by NADPH oxidases in the embryo and aleurone cells in barley seed germination. PLoS ONE 2015, 10, e0143173. [CrossRef]

43. Fontaine, O.; Billard, J.P.; Huault, C. Effect of glutathione on dormancy breakage in barley seeds. Plant Growth Regul. 1995, 16, 55-58. [CrossRef]

44. Kalemba, E.M.; Ratajczak, E. The effect of a doubled glutathione level on parameters affecting the germinability of recalcitrant Acer saccharinum seeds during drying. J. Plant Physiol. 2018, 223, 72-83. [CrossRef]

45. Miao, Y.; Lv, D.; Wang, P.; Wang, X.C.; Chen, J.; Miao, C.; Song, C.P. An Arabidopsis glutathione peroxidase functions as both a redox transducer and a scavenger in abscisic acid and drought stress responses. Plant Cell 2006, 18, 2749-2766. [CrossRef]

46. Chen, J.H.; Jiang, H.W.; Hsieh, E.J.; Chen, H.Y.; Chien, C.T.; Hsieh, H.L.; Lin, T.P. Drought and salt stress tolerance of an Arabidopsis glutathione S-transferase U17 knockout mutant are attributed to the combined effect of glutathione and abscisic acid. Plant Physiol. 2012, 158, 340-351. [CrossRef]

47. Wu, J.; Zhang, N.; Liu, Z.; Liu, S.; Liu, C.; Lin, J.; Yang, H.; Li, S.; Yukawa, Y. The AtGSTU7 gene influences glutathione-dependent seed germination under ABA and osmotic stress in Arabidopsis. Biochem. Biophys. Res. Commun. 2020, 528, 538-544. [CrossRef]

48. Paiva, A.L.S.; Passaia, G.; Jardim-Messeder, D.; Nogueira, F.C.S.; Domont, G.B.; Margis-Pinheiro, M. The mitochondrial isoform glutathione peroxidase 3 (OsGPX3) is involved in ABA responses in rice plants. J. Proteom. 2021, 232, 104029. [CrossRef]

49. Wang, P.; Zhu, J.K.; Lang, Z. Nitric oxide suppresses the inhibitory effect of abscisic acid on seed germination by S-nitrosylation of SnRK2 proteins. Plant Signal. Behav. 2015, 10, e1031939. [CrossRef]

50. Xu, F.; Tang, J.; Gao, S.; Cheng, X.; Du, L.; Chu, C. Control of rice pre-harvest sprouting by glutaredoxin-mediated abscisic acid signaling. Plant J. 2019, 100, 1036-1051. [CrossRef] [PubMed]

51. Bela, K.; Horváth, E.; Gallé, Á.; Szabados, L.; Tari, I.; Csiszár, J. Plant glutathione peroxidases: Emerging role of the antioxidant enzymes in plant development and stress responses. J. Plant Physiol. 2015, 176, 192-201. [CrossRef] [PubMed]

52. Zhai, C.; Zhao, L.; Yin, L.; Chen, M.; Wang, Q.; Li, L.; Xu, Z.; Ma, Y. Two wheat glutathione peroxidase genes whose products are located in chloroplasts improve salt and $\mathrm{H}_{2} \mathrm{O}_{2}$ tolerances in Arabidopsis. PLoS ONE 2013, 8, e73989. [CrossRef] [PubMed]

53. Marrs, K.A. The functions and regulation of glutathione s-transferases in plants. Annu. Rev. Plant Physiol. Plant Mol. Biol. 1996, 47, 127-158. [CrossRef]

54. Xu, J.; Tian, Y.; Xing, X.; Peng, R.; Zhu, B.; Gao, J.; Yao, Q. Over-expression of AtGSTU19 provides tolerance to salt, drought and methyl viologen stresses in Arabidopsis. Physiol. Plant. 2016, 156, 164-175. [CrossRef] [PubMed]

55. Sharma, R.; Sahoo, A.; Devendran, R.; Jain, M. Over-expression of a rice tau class glutathione S-transferase gene improves tolerance to salinity and oxidative stresses in Arabidopsis. PLoS ONE 2014, 9, e92900. [CrossRef] [PubMed]

56. Gao, C.; Yang, G.; Guo, Y.; Zhao, Y.; Yang, C. Overexpression of ThGSTZ1 from Tamarix hispida improves tolerance to exogenous ABA and methyl viologen. Trees-Struct. Funct. Trees-Struct. Funct. 2016, 30, 1935-1944. [CrossRef]

57. Wu, Q.; Yang, J.; Cheng, N.; Hirschi, K.D.; White, F.F.; Park, S. Glutaredoxins in plant development, abiotic stress response, and iron homeostasis: From model organisms to crops. Environ. Exp. Bot. 2017, 139, 91-98. [CrossRef]

58. Rouhier, N.; Gelhaye, E.; Jacquot, J.P. Plant glutaredoxins: Still mysterious reducing systems. Cell Mol. Life Sci. 2004, 61, 1266-1277. [CrossRef]

59. Ruan, M.-B.; Yang, Y.L.; Li, K.M.; Guo, X.; Wang, B.; Yu, X.L.; Peng, M. Identification and characterization of drought-responsive CC-type glutaredoxins from cassava cultivars reveals their involvement in ABA signalling. BMC Plant Biol. 2018, 18, 329. [CrossRef]

60. $\mathrm{Hu}, \mathrm{Y}$. The roles of Glutaredoxin grxs17 in Improving Chilling Tolerance in Tomato and Drought Tolerance in Rice via Different Mechanisms. Ph.D. Thesis, Kansas State University, Manhattan, KS, USA, 2015.

61. Li, S. Redox modulation matters: Emerging functions for glutaredoxins in plant development and stress responses. Plants 2014, 3, 559-582. [CrossRef]

62. Albertos, P.; Romero-Puertas, M.C.; Tatematsu, K.; Mateos, I.; Sánchez-Vicente, I.; Nambara, E.; Lorenzo, O. S-nitrosylation triggers ABI5 degradation to promote seed germination and seedling growth. Nat. Commun. 2015, 6, 8669. [CrossRef]

63. Liu, Y.; Shi, L.; Ye, N.; Liu, R.; Jia, W.; Zhang, J. Nitric oxide-induced rapid decrease of abscisic acid concentration is required in breaking seed dormancy in Arabidopsis. New Phytol. 2009, 183, 1030-1042. [CrossRef]

64. Broniowska, K.A.; Diers, A.R.; Hogg, N. S-nitrosoglutathione. Biochim. Biophys. Acta 2013, 1830, 3173-3181. [CrossRef] 
65. Kailasam, S.; Wang, Y.; Lo, J.C.; Chang, H.F.; Yeh, K.C. S-Nitrosoglutathione works downstream of nitric oxide to mediate iron-deficiency signaling in Arabidopsis. Plant J. 2018, 94, 157-168. [CrossRef]

66. Ciacka, K.; Krasuska, U.; Otulak-Kozieł, K.; Gniazdowska, A. Dormancy removal by cold stratification increases glutathione and S-nitrosoglutathione content in apple seeds. Plant Physiol. Biochem. 2019, 138, 112-120. [CrossRef] [PubMed]

67. Bharath, P.; Gahir, S.; Raghavendra, A.S. Abscisic acid-induced stomatal closure: An important component of plant defense against abiotic and biotic stress. Front. Plant Sci. 2021, 12, 615114. [CrossRef] [PubMed]

68. Agurla, S.; Gahir, S.; Munemasa, S.; Murata, Y.; Raghavendra, A.S. Mechanism of stomatal closure in plants exposed to drought and cold stress. In Survival Strategies in Extreme Cold and Dessication; Iwaya-Inoue, M., Sakurai, M., Uemura, M., Eds.; Springer: Singapore, 2018; pp. 215-232.

69. Jahan, M.S.; Ogawa, K.; Nakamura, Y.; Shimoishi, Y.; Mori, I.C.; Murata, Y. Deficient glutathione in guard cells facilitates abscisic acid-induced stomatal closure but does not affect light-induced stomatal opening. Biosci. Biotechnol. Biochem. 2008, 72, $2795-2798$. [CrossRef]

70. Jahan, S.; Nozulaidi, M.; Khairi, M.; Mat, N. Light-harvesting complexes in photosystem II regulate glutathione-induced sensitivity of Arabidopsis guard cells to abscisic acid. J. Plant Physiol. 2016, 195, 1-8. [CrossRef] [PubMed]

71. Batool, S.; Uslu, V.V.; Rajab, H.; Ahmad, N.; Waadt, R.; Geiger, D.; Malagoli, M.; Xiang, C.B.; Hedrich, R.; Rennenberg, H.; et al. Sulfate is incorporated into cysteine to trigger ABA Production and stomatal closure. Plant Cell 2018, 30, 2973-2987. [CrossRef] [PubMed]

72. Rajab, H.; Khan, M.S.; Malagoli, M.; Hell, R.; Wirtz, M. Sulfate-induced stomata closure requires the canonical ABA signal transduction machinery. Plants (Basel) 2019, 8, 21. [CrossRef] [PubMed]

73. Bittner, F.; Oreb, M.; Mendel, R.R. ABA3 Is a molybdenum cofactor sulfurase required for activation of aldehyde oxidase and xanthine dehydrogenase in Arabidopsis thaliana. J. Biol. Chem. 2001, 276, 40381-40384. [CrossRef] [PubMed]

74. Akter, N.; Sobahan, M.A.; Uraji, M.; Ye, W.; Hossain, M.A.; Mori, I.C.; Nakamura, Y.; Murata, Y. Effects of depletion of glutathione on abscisic acidand methyl jasmonate-induced stomatal closure in Arabidopsis thaliana. Biosci. Biotechnol. Biochem. 2012, 76, 2032-2037. [CrossRef] [PubMed]

75. Pei, Z.; Murata, Y.; Benning, G.; Thomine, Â.; Klu, B.; Allen, G.J.; Grill, E. Calcium channels activated by hydrogen peroxide mediate abscisic acid signalling in guard cells. Nature 2000, 190, 731-734. [CrossRef]

76. Nishimura, N.; Sarkeshik, A.; Nito, K.; Park, S.Y.; Wang, A.; Carvalho, P.C.; Lee, S.; Caddell, D.F.; Cutler, S.R.; Chory, J.; et al. PYR/PYL/RCAR family members are major in-vivo ABI1 protein phosphatase 2C-interacting proteins in Arabidopsis. Plant J. 2010, 61, 290-299. [CrossRef] [PubMed]

77. Murata, Y.; Pei, Z.M.; Mori, I.C.; Schroeder, J. Abscisic acid activation of plasma membrane $\mathrm{Ca}^{2+}$ channels in guard cells requires cytosolic $\mathrm{NAD}(\mathrm{P}) \mathrm{H}$ and is differentially disrupted upstream and downstream of reactive oxygen species production in abi1-1 and abi2-1 protein phosphatase 2C mutants. Plant Cell 2001, 13, 2513-2523. [CrossRef] [PubMed]

78. Pan, W.; Lin, B.; Yang, X.; Liu, L.; Xia, R.; Li, J.; Wu, Y.; Xie, Q. The UBC27-AIRP3 ubiquitination complex modulates ABA signaling by promoting the degradation of ABI1 in Arabidopsis. Proc. Natl. Acad. Sci. USA 2020, 117, 27694-27702. [CrossRef] [PubMed]

79. Dixon, D.P.; Skipsey, M.; Grundy, N.M.; Edwards, R. Stress-induced protein S-glutathionylation in Arabidopsis. Plant Physiol. 2005, 138, 2233-2244. [CrossRef]

80. Demasi, M.; Hand, A.; Ohara, E.; Oliveira, C.L.P.; Bicev, R.N.; Bertoncini, C.A.; Netto, L.E.S. 20 S proteasome activity is modified via $S$-glutathionylation based on intracellular redox status of the yeast Saccharomyces cerevisiae: Implications for the degradation of oxidized proteins. Arch. Biochem. Biophys. 2014, 557, 65-71. [CrossRef]

81. Sah, S.K.; Reddy, K.R.; Li, J. Abscisic acid and abiotic stress tolerance in crop plants. Front. Plant Sci. 2016, 7, 571. [CrossRef]

82. Tuteja, N. Abscisic acid and abiotic stress signaling. Plant Signal. Behav. 2007, 2, 135-138. [CrossRef]

83. Du, Y.L.; Wang, Z.Y.; Fan, J.W.; Turner, N.; He, J.; Wang, T.; Li, F.M. Exogenous abscisic acid reduces water loss and improves antioxidant defence, desiccation tolerance and transpiration efficiency in two spring wheat cultivars subjected to a soil water deficit. Funct. Plant Biol. 2013, 40, 494-506. [CrossRef]

84. Wei, L.; Wang, L.; Yang, Y.; Wang, P.; Guo, T.; Kang, G. Abscisic acid enhances tolerance of wheat seedlings to drought and regulates transcript levels of genes encoding ascorbate-glutathione biosynthesis. Front. Plant Sci. 2015, 6, 458. [CrossRef]

85. Zhou, Y.; He, R.; Guo, Y.; Liu, K.; Huang, G.; Peng, C.; Liu, Y.; Zhang, M.; Li, Z.; Duan, L. A novel ABA functional analogue B2 enhances drought tolerance in wheat. Sci. Rep. 2019, 9, 2887. [CrossRef] [PubMed]

86. Skowron, E.; Trojak, M. Effect of exogenously-applied abscisic acid, putrescine and hydrogen peroxide on drought tolerance of barley. Biologia (Bratisl) 2021, 76, 453-468. [CrossRef]

87. Teng, K.; Li, J.; Liu, L.; Han, Y.; Du, Y.; Zhang, J.; Sun, H.; Zhao, Q. Exogenous ABA induces drought tolerance in upland rice: The role of chloroplast and ABA biosynthesis-related gene expression on photosystem II during PEG stress. Acta Physiol. Plant. 2014, 36, 2219-2227. [CrossRef]

88. Li, C.-N.; Yang, L.-T.; Srivastava, M.K.; Li, Y.-R. Foliar application of abscisic acid improves drought tolerance of sugarcane plant under severe water stress. Int. J. Agric. Innov. Res. 2014, 3, 101-107.

89. Gai, Z.; Wang, Y.; Ding, Y.; Qian, W.; Qiu, C.; Xie, H.; Sun, L.; Jiang, Z.; Ma, Q.; Wang, L.; et al. Exogenous abscisic acid induces the lipid and flavonoid metabolism of tea plants under drought stress. Sci. Rep. 2020, 10, 12275. [CrossRef] 
90. Thompson, A.J.; Jackson, A.C.; Parker, R.A.; Morpeth, D.R.; Taylor, I.B. Abscisic acid biosynthesis in tomato: Regulation of zeaxanthin epoxidase and 9- cis -epoxycarotenoid dioxygenase mRNAs by light / dark cycles, water stress and abscisic acid. Plant Mol. Biol. 2000, 42, 833-845. [CrossRef]

91. Bao, G.; Zhuo, C.; Qian, C.; Xiao, T.; Guo, Z.; Lu, S. Co-expression of NCED and ALO improves vitamin C level and tolerance to drought and chilling in transgenic tobacco and stylo plants. Plant Biotechnol. J. 2016, 14, 206-214. [CrossRef]

92. Estrada-Melo, A.C.; Ma, C.; Reid, M.S.; Jiang, C.Z. Overexpression of an ABA biosynthesis gene using a stress-inducible promoter enhances drought resistance in petunia. Hortic. Res. 2015, 2, 15013. [CrossRef]

93. Tian, X.; Wang, Z.; Li, X.; Lv, T.; Liu, H.; Wang, L.; Niu, H.; Bu, Q. Characterization and functional analysis of pyrabactin resistance-like abscisic acid receptor family in rice. Rice 2015, 8, 28. [CrossRef]

94. González-guzmán, M.; Rodríguez, L.; Lorenzo-orts, L.; Pons, C.; Sarrión-, A.; Fernández, M.A.; Peirats-llobet, M.; Forment, J.; Moreno-alvero, M.; Cutler, S.R.; et al. Tomato PYR / PYL / RCAR abscisic acid receptors show high expression in root, differential sensitivity to the abscisic acid agonist quinabactin, and the capability to enhance plant drought resistance. J. Exp. Bot. 2014, 65, 4451-4464. [CrossRef] [PubMed]

95. Sarker, U.; Oba, S. Drought stress enhances nutritional and bioactive compounds, phenolic acids and antioxidant capacity of Amaranthus leafy vegetable. BMC Plant Biol. 2018, 18, 258. [CrossRef] [PubMed]

96. Jiang, M.; Zhang, J. Water stress-induced abscisic acid accumulation triggers the increased generation of reactive oxygen species and up-regulates the activities of antioxidant enzymes in maize leaves. J. Exp. Bot. 2002, 53, 2401-2410. [CrossRef] [PubMed]

97. Xing, X.; Zhou, Q.; Xing, H.; Jiang, H.; Wang, S. Early abscisic acid accumulation regulates ascorbate and glutathione metabolism in soybean leaves under progressive water stress. J. Plant Growth Regul. 2016, 35, 865-876. [CrossRef]

98. Galle, A.; Csiszar, J.; Secenji, M.; Forest, L.; Benyo, D.; Gyorgyey, J. Induction and regulation of glutathione transferases in wheat species exposed to PEG induced osmotic stress. Acta Biol. Szeged. 2011, 55, 79-80. [CrossRef]

99. Srivastava, D.; Verma, G.; Chauhan, A.S.; Pande, V.; Chakrabarty, D. Rice (Oryza sativa L.) tau class glutathione S-transferase (OsGSTU30) overexpression in Arabidopsis thaliana modulates a regulatory network leading to heavy metal and drought stress tolerance. Metallomics 2019, 11, 375-389. [CrossRef]

100. Nianiou-Obeidat, I.; Madesis, P.; Kissoudis, C.; Voulgari, G.; Chronopoulou, E.; Tsaftaris, A.; Labrou, N.E. Plant glutathione transferase-mediated stress tolerance: Functions and biotechnological applications. Plant Cell Rep. 2017, 36, 791-805. [CrossRef] [PubMed]

101. Mailloux, R.J. Redox Biology Protein S-glutathionylation reactions as a global inhibitor of cell metabolism for the desensitization of hydrogen peroxide signals. Redox Biol. 2020, 32, 101472. [CrossRef]

102. Clark, G.; Konopka-Postupolska, D.; Hennig, J.; Roux, S. Is annexin 1 a multifunctional protein during stress responses? Plant Signal. Behav. 2010, 5, 303-307. [CrossRef]

103. Konopka-Postupolska, D.; Clark, G.; Goch, G.; Debski, J.; Floras, K.; Cantero, A.; Fijolek, B.; Roux, S.; Hennig, J. The role of annexin 1 in drought stress in Arabidopsis. Plant Physiol. 2009, 150, 1394-1410. [CrossRef]

104. Ijaz, R.; Ejaz, J.; Gao, S.; Liu, T.; Imtiaz, M.; Ye, Z.; Wang, T. Overexpression of annexin gene AnnSp2, enhances drought and salt tolerance through modulation of ABA synthesis and scavenging ROS in tomato. Sci. Rep. 2017, 7, 12087. [CrossRef]

105. Li, X.; Zhang, Q.; Yang, X.; Han, J.; Zhu, Z. OsANN3, a calcium-dependent lipid binding annexin is a positive regulator of ABA-dependent stress tolerance in rice. Plant Sci. 2019, 284, 212-220. [CrossRef]

106. Gomez, L.D.; Noctor, G.; Knight, M.R.; Foyer, C.H. Regulation of calcium signalling and gene expression by glutathione. J. Exp. Bot. 2004, 55, 1851-1859. [CrossRef]

107. Li, F.; Wang, J.; Ma, C.; Zhao, Y.; Wang, Y.; Hasi, A.; Qi, Z. Glutamate receptor-like channel3.3 is involved in mediating glutathionetriggered cytosolic calcium transients, transcriptional changes, and innate immunity responses in Arabidopsis. Plant Physiol. 2013, 162, 1497-1509. [CrossRef] [PubMed]

108. Ahmad, N.; Malagoli, M.; Wirtz, M.; Hell, R. Drought stress in maize causes differential acclimation responses of glutathione and sulfur metabolism in leaves and roots. BMC Plant Biol. 2016, 16, 247. [CrossRef] [PubMed]

109. Cao, M.; Wang, Z.; Wirtz, M.; Hell, R.; Oliver, D.J.; Xiang, C. SULTR3; 1 is a chloroplast-localized sulfate transporter in Arabidopsis thaliana. Plant J. 2013, 73, 607-616. [CrossRef] [PubMed] 